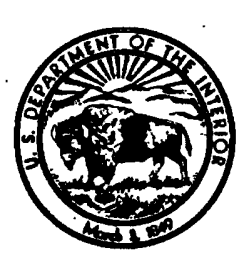

Department of the Interior

U.S. Geological Survey

\title{
Preliminary Map of Landslide Features and Coseismic Fissures in the Summit Road Area of the Santa Cruz Mountains Triggered by the Loma Prieta Earthquake of October 17, 1989
}

\author{
Compiled by \\ Thomas E. Spittler and Edwin L. Harp \\ With assistance from:
}

Alan Bartow, R. L. Baum, T. L. Bedrossian, W. A. Bryant, R. C. Bucknam, R. E. Burton, R. H. Campbell, M. D. Carr, M. M. Clark, Patience Cowie, K. H. Custis, T. E. Fumal, S. E. Goodin, R. B. Greenwood, K. M. Haller, D. F. Harwood, J. P. Hayes, C. A. Hoadley, J. K. Howard, P. J. Irvine, R. W. Jibson, D. K. Keefer, K. L. Lajoie, Paia Levine, J. J. Leinkaemper, R. P. Lozinsky, M. N. Machette, M. W. Manson, M. A. McKittrick, S. L. Miller, J. E. Nielson, J. M. Nolan, Lyne Perry, S. F. Personius, D. J. Ponti, C. E. Prentice, Z. Reches, R. H. Rice, G. J. Saucedo, J. A. Schlosser, Kevin Schmidt, D. E. Schwartz, J. A. Sowma, R. H. Sydnor, S. S. Tan, J. A. Treiman, D. L. Wagner, Brian Walls, G. E. Weber, R. E. Wells, Robert Whitney, R. C. Wilson, and Peter Wood

\section{OPEN-FILE REPORT 90-688}

(Also released as California Division of Mines and Geology Report 90-6)

This report is preliminary and has not been reviewed for conformity

with U.S. Geological Survey editorial standards (or with the North American Stratigraphic Code).

Any use of trade, product, or firm names is for descriptive purposes only and does not imply endorsement by the U.S. Government.

Menlo Park, California 


\title{
Preliminary Map of Landslide Features and Coseismic Fissures in the Summit Road Area of the Santa Cruz Mountains Triggered by the Loma Prieta Earthquake of October 17, 1989
}

\author{
Compiled by \\ Thomas E. Spittler ${ }^{1}$ and Edwin L. Harp 2
}

With assistance from:

Alan Bartow 2, R. L. Baum ${ }^{2}$, T. L. Bedrossian 1 , W. A. Bryant ${ }^{1}$, R. C. Bucknam $^{2}$, R. E. Burton 5 , R. H. Campbell ${ }^{2}$, M. D. Carr ${ }^{2}$, M. M. Clark ${ }^{2}$, Patience Cowie 8 , K. H. Custis 1 , T. E. Fumal ${ }^{2}$, S. E. Goodin 7 , R. B.

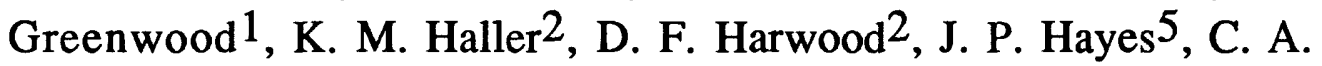
Hoadley $^{1}$, J. K. Howard 1 , P. J. Irvine ${ }^{1}$, R. W. Jibson ${ }^{2}$, D. K. Keefer ${ }^{2}$, K. L. Lajoie ${ }^{2}$, Paia Levine ${ }^{3}$, J. J. Leinkaemper ${ }^{2}$, R. P. Lozinsky 4 , M. N. Machette $^{2}$, M. W. Manson'1, M. A. McKittrick ${ }^{3}$, S. L. Miller ${ }^{5}$, J. E. Nielson$^{2}$, J. M. Nolan6, Lyne Perry 4 , S. F. Personius ${ }^{2}$, D. J. Ponti ${ }^{2}$, C. E. Prentice $^{2}$, Z. Reches 9 , R. H. Rice ${ }^{7}$, G. J. Saucedo ${ }^{1}$, J. A. Schlosser ${ }^{1}$, Kevin Schmidt ${ }^{2}$, D E. Schwartz ${ }^{2}$, J. A. Sowma ${ }^{1}$, R. H. Sydnor ${ }^{1}$, S. S. Tan $^{1}$, J. A. Treiman 1 , D. L. Wagner ${ }^{1}$, Brian Walls ${ }^{10}$, G. E. Weber 5 , R. E. Wells $^{2}$, Robert Whitney 4 , R. C. Wilson ${ }^{2}$, and Peter Wood 11

1 California Department of Conservation, Division of Mines and Geology, Sacramento, Pleasant Hill, Los Angeles, Santa Rosa, and Ukiah, California.

${ }^{2}$ U.S. Geological Survey, Menlo Park, California, Denver, Colorado, and Reston, Virginia.

${ }^{3}$ County of Santa Cruz, Santa Cruz, California.

${ }^{4}$ Leighton \& Associates, Irvine, Diamond Bar, San Diego, and Sanata Ana, California.

5 Weber and Associates, Watsonville, California.

6J. M. Nolan Consultant, Santa Cruz, California.

${ }^{7}$ Dames \& Moore, San Frnancisco, California.

${ }^{8}$ Lamont Doherty Geophysical Observatory, Pallisades, New York.

${ }^{9}$ Hebrew University, Jerusalem, Israel.

${ }^{10}$ U.S. Army Corps of Engineers.

${ }^{11}$ New Zealand Geological Survey, Lower Hutt, New Zealand. 


\section{Introduction}

Extensive landsliding and coseismic fissuring occurred in the Santa Cruz Mountains in the southern portion of the San Francisco Bay area during the $M=7.1$ Loma Prieta, California earthquake of October 17, 1989. An initial systematic reconnaissance of the epicentral area defined the limits of a 3,500 ha area in which the most concentrated large-scale landslide deformation and coseismic fissuring occurred. The landslides and other fissures destroyed or damaged more than 100 residential structures and may pose further hazards from renewed movement in response to winter rainfall and subsequent high ground-water levels. Following the initial survey, the California Department of Conservation's Division of Mines and Geology (DMG) and the U.S. Geological Survey (USGS), assisted by geologists from other public and private agencies, prepared this set of maps to show observed surface features that occurred during the October 17, 1989 earthquake. The earthquake triggered significant landslides in other areas as well; these areas are briefly outlined U.S. Geological Survey Staff (1989) and Plafker and Galloway (1989).

\section{Description of Features}

Landslides and coseismic fissures are most abundant on the southwestern flank of the ridge on which Summit Road is located, between its intersection of with Highway 17 and Highland Way. This area is adjacent to the surface trend of the San Andreas fault and lies northwest of the earthquake epicenter (fig. 1, pl. 1-3).

An extensive network of interwoven fractures and fissures formed during the earthquake and dissected the summit ridge in a complicated pattern. This network of fractures presented a complex picture for geologists to interpret in the context of a dominantly right-lateral strike-slip fault zone. Most of the shear fractures had left-lateral displacement. Fractures also tended to be discontinuous. Even the larger fractures, some of them several meters wide and having as much as $1 \mathrm{~m}$ of displacement, generally extended less than $400 \mathrm{~m}$. The majority of fractures showed extension as the dominant component of the total displacement. Some of the fissures are interpreted as being tectonic in origin, while numerous fractures form headwall scarps and lateral margins of deep-seated rotational slumps or translational block slides. The landslide nomenclature used here is that of Varnes (1978). 
Most readily recognizable among landslide-related cracks are extension fractures, commonly located along preexisting headwall scarps. These fractures have the largest displacements of all the landslide-related cracks. Displacements across the scarps of the deep-seated slumps along Schultheis Road and Morell Cutoff Road exceed $1.0 \mathrm{~m}$ (pl. 1 and 2). The sense of displacements across fissures forming these scarps is extensional and similar to a normal fault, valley side down.

Fractures that formed along flanks of landslides generally exhibit shear displacement consistent with the relative displacement of the landslide mass; however, in numerous areas (1) the relative displacement of the landslide mass is not clear, and (2) the relation of the sense of displacement across individual cracks to the overall mass movement also is unclear. The least common deformational features related to the earthquake-triggered landslides are welldefined folds and fractures along the toes of landslides.

Fractures and fissures interpreted as being of tectonic origin include cracks located along linear ridge-top depressions and linear fractures that extend across well-defined landslide features. Some of these may have resulted from shear displacement along bedding planes of the steeply dipping sandstone and shale formations (Cotton and others, 1990). However, other fissures may have formed as extensional partings along bedding or jointing within the underlying sedimentary formations. The presence of uphill-facing scarps along such fractures in the absence of landslide features suggests a tectonic origin, although this relationship in itself is not conclusive. Some uphill-facing scarps may have been formed by lateral bulging of the summit ridge with resultant subsidence of a ridge-top trough (sacküng).

Extensional fractures along the crests of narrow, steep-sided ridge tops occurred in several areas south of Summit Road. The most spectacular example of ridge-crest fracturing occurred along Robin Wood Way, a private road that extends along a ridge crest approximately $4 \mathrm{~km}$ south of the junction of Summit Road with San Jose-Soquel Road (pl. 3). Here, extension fractures penetrated through soil into weathered bedrock and were adjacent to woodframe houses that showed evidence of extraordinary levels of strong shaking; walls were torn from the houses and, in some cases, the structures completely collapsed. Rocks, concrete slabs, and logs in this area also were found displaced from their original positions with 
little or no evidence of transport by rolling. Rather, the objects appeared to have been thrown from their original positions to their present ones by vertical accelerations of greater than $1.0 \mathrm{~g}$. The fractures present along ridges such as those along Robin Wood Way are interpreted as having formed in response to surficial tensional stresses induced by extremely high levels of seismic shaking. In many areas, the ridge-top fractures end where ridges widen to greater than $100 \mathrm{~m}$ or where slopes are less than $24^{\circ}$. In most areas, the ridge-top fissures are parallel to bedding or jointing of the underlying sedimentary formations.

\section{$\underline{\text { Accuracy }}$}

The base map used for this compilation is a $1: 4,800$-scale planimetric base prepared by the County of Santa Cruz, which shows property boundaries and cultural features. In the Summit Road area, most field mapping was done using 1:6,000-scale aerial photography flown October 27, 1989. In areas beyond this coverage, mapping was done on 1:4,800 enlargements of 1:24,000-scale USGS topographic maps, 1:31,680-scale black-and-white aerial photographs taken in June, 1989, and directly on the Santa Cruz County planimentric maps.

Location errors of fractures and other features were introduced through transfer problems and from the apparent scale errors in the county map base. Locations of features mapped from 1:6,000-scale airphotos are accurate to within $10 \mathrm{~m}$ where vegetation is sparse and to within $10-50 \mathrm{~m}$ where tree cover is dense. Outside the coverage of the 1:6,000-scale aerial photos, locations are less accurate. In areas with distinctive cultural or topographic features, the accuracy is estimated to be within 20 to $50 \mathrm{~m}$. Where no distinct features are shown on the base maps or on the 1:31,680-scale aerial photos, and where the tree cover is dense, the location accuracy is estimated to be within 50 to $100 \mathrm{~m}$.

Some landslide features and coseismic fissures may have been missed during the mapping because of dense vegetation, poor access, and the obliteration of many features due to repair work before mapping could be completed. The purpose of this map is to document the landslides and coseismic fractures in a systematic way and to display their distribution with a minimum of generalization. Because the features have been plotted by hand and not precisely surveyed at a large scale such as 1:500 or greater, some generalization has been incorporated in the mapping. Therefore these maps are useful 
as a reconnaissance tool and as a guide subsequent geologic and geotechnical investigations, but they are not sufficiently precise to serve as maps upon which to base site-specific engineering or planning decisions.

\section{References}

Cotton, W.R., Fowler, W.L., and Van Velsor, J.E., 1990, Coseismic bedding-plane faults and ground fissures associated with the Loma Prieta earthquake of October 17, 1989, in McNutt, S. R., and Sydnor, R.H., eds., The Loma Prieta "Santa Cruz" Mountains, California Earthquake of 17 October 1989::California Division of Mines and Geology Special Publication 104, p. 95-103.

Harp, E.L., 1990, The Morrell Cutoff Landslide: An example of a deepseated rotational slump triggered by the October 17, 1989, Loma Prieta earthquake, in, Schwartz, D.P., and Ponti, D.J., eds., Field Guide to Neotectonics of the San Andreas Fault System, Santa Cruz Mountains, in Light of the 1989 Loma Prieta Earthquake, U.S. Geological Survey Open-File Report 90-274, p. 16-19.

Lawson, A.C., and others, 1908, The California earthquake of April 18, 1906, Report of the State Earthquake Investigations

Commission: Carnegie Institute of Washington Publication 87, v. $1,451 \mathrm{p}$.

Ponti, D.J., and Wells, R.E., 1990, Extent and origin of surface fractures in the Summit Road-Skyland Ridge area, in Schwartz, D.P., and Ponti, D.J., Field Guide to Neotectonics of the San Andreas Fault System, Santa Cruz Mountains, in Light of the 1989 Loma Prieta Earthquake, U.S. Geological Survey Open-File Report 90-274, p. 27-30.

Varnes, D.J., 1978, Slope movement types and processes, in Schuster, R.L., and Krizek, R.J., eds., Landslides Analysis and Control::

Transportation Research Board Special Publication 176, National Academy of Sciences, p. 11-33, 1 pl. 
Appendix A

\section{Description of Major Features}

Morrill Road Fracture ${ }^{1}$

This fracture extends northwest-southeast for over $300 \mathrm{~m}$ and has a maximum displacement of $54 \mathrm{~cm}$. Its sense of displacement is left lateral since its azimuth is $\mathrm{N} 32 \mathrm{~W}$, and its displacement vector azimuth is N7E with an $11^{\circ}$ plunge. The fracture crosses Morrill Road approximately $120 \mathrm{~m}$ north of the intersection with Summit Road and extends southeastward through an orchard where it could still be observed 6 months after the earthquake. To the northwest, surface breakage along this fracture becomes discontinuous. Within the orchard east of Morrill Road, the fracture extends southeast almost to Summit Road before it curves to the east and begins to describe an arcuate path that could be the margin of a landslide, although the cracks end about $10 \mathrm{~m}$ beyond where they begin to curve to the east. The sense of displacement on this fracture is consistently left lateral and down to the north.

Another associated fracture is a right lateral fracture that crosses Morrill Road only $30 \mathrm{~m}$ north of the intersection with Summit Road and trends N50W. Its maximum dispacement is $17 \mathrm{~cm}$ with a total length of more than $600 \mathrm{~m}$. It extends to the southeast and crosses part of the soccer field just northeast of C. T. English school (pl. 2, see notes 23-17 and 23-31). Several locations along this fracture show a sense of vertical displacement of up to the southwest. The Morrill Road fractures are especially significant because their displacements from the 1989 earthquake can be compared with recorded displacements from the 1906 San Francisco earthquake (Lawson and others, 1908).

Morrell Cutoff Landslide 2

The right flank (looking downslope) of this landslide crosses Morrell Cutoff Road about $0.6 \mathrm{~km}$ south of its intersection with Summit Road. Here, the road and a white painted wooden fence was offset in a right lateral sense (Pl. 2, see note 23-24). The cracks that form this lateral shear zone extend upslope to the north for about

${ }^{1}$ Displacement data from Ponti and others (1990).

${ }^{2}$ Summarized from Harp (1990). 
$100 \mathrm{~m}$, where they curve to the northeast and form an arcuate headwall scarp about $100 \mathrm{~m}$ long. The headwall scarp crosses a gravel road in a Christmas tree farm where the cracks in the zone are as much as $3 \mathrm{~m}$ deep and $1 \mathrm{~m}$ wide. In the headwall area, the cracks define a 20-m-wide zone with downslope-facing scarps and extensive graben development. From the intersection of the gravel road with the headwall scarp zone, the cracks extend almost $600 \mathrm{~m}$ to the east,where they become discontinuous without curving to the southeast to define a left flank of the landslide.

Along the right flank of the landslide, south of where the lateral shear zone crosses Morrell Cutoff Road, the cracks make an abrupt change in trend from N10E to N60W and continue almost 200 $m$ to the northwest before dying out. Individual fractures in this northwest-trending zone exhibit upslope-facing scarps with as much as $10 \mathrm{~cm}$ of vertical displacement.

From the headwall scarp area to Morrell Cutoff Road, slopes on thd landslide decrease from $25^{\circ}-35^{\circ}$ to $0^{\circ}-15^{\circ}$. South of the road, the slope faces to the north at about 50 as the toe of the landslide is encountered near the house on the Clindt property. The toe is expressed as a gentle antiform that trends roughly east-west. Just south of the Clindt house, the slope dips gently to the south. A narrow zone of fractures occupies the crest of the toe ridge and was traced eastward along its axis for $400 \mathrm{~m}$. The cracks within this zone were mainly extensional with 20 -to $30-\mathrm{cm}$ displacements, and graben several meters wide developed between cracks.

Tranbarger Fracture ${ }^{3}$

This major fracture extends more than $100 \mathrm{~m}$ from northwest to southeast. At the northwest end, displacement has produced a scarp showing $15 \mathrm{~cm}$ vertical movement, down to the south with mainly left-lateral horizontal displacement. The deformation includes a series of right-stepping cracks with both left-and right-lateral displacement. To the southeast, a drainage is crossed by the crack zone which becomes a double scarp with $30 \mathrm{~cm}$ of vertical displacement (down to the south) and $5-15 \mathrm{~cm}$ of extension.

Where the scarps cross Summit Road, there is approximately $30 \mathrm{~cm}$ of left-lateral offset in the road. Southeast of Summit Road, the vertical movement is mainly down to the southwest and was traced for about $400 \mathrm{~m}$ in this direction.

${ }^{3}$ Displacement data summarized from D.K. Keefer, U.S. Geological Survey 
Schultheis Road Landslide 4

The Schultheis Road landslide is one of best defined landslides triggered by the Loma Prieta earthquake as well as one of the largest. Its right flank or lateral shear surface crosses Schultheis Road approximately $0.5 \mathrm{~km}$ from its junction with Old Santa Cruz highway. The landslide is about $400 \mathrm{~m}$ long along its downslope axis. Its headwall scarp consists of multiple fractures (see Plate 1), the uppermost of which has more than $1 \mathrm{~m}$ of horizontal and $45 \mathrm{~cm}$ of vertical displacement; this scarp was open to depths of almost $3 \mathrm{~m}$.

The lateral shears that make up both flanks of the landslide are well developed. The left flank lateral shear surface curves in toward the landslide axis about halfway down the length of the landslide with the result that thrusting occurs as the landslide mass overrides its lateral boundary. This occurs immediately northeast of the side road that leaves Schultheis Road toward the southeast (see Plate 1). Other compressional features occur near the left flank of the landslide about $400 \mathrm{~m}$ from the headwall scarp (see note $3-40$, pl.1).

4 Displacement data summarized from D.K. Keefer and R.W. Jibson, U.S. Geological Survey, unpublished data. 


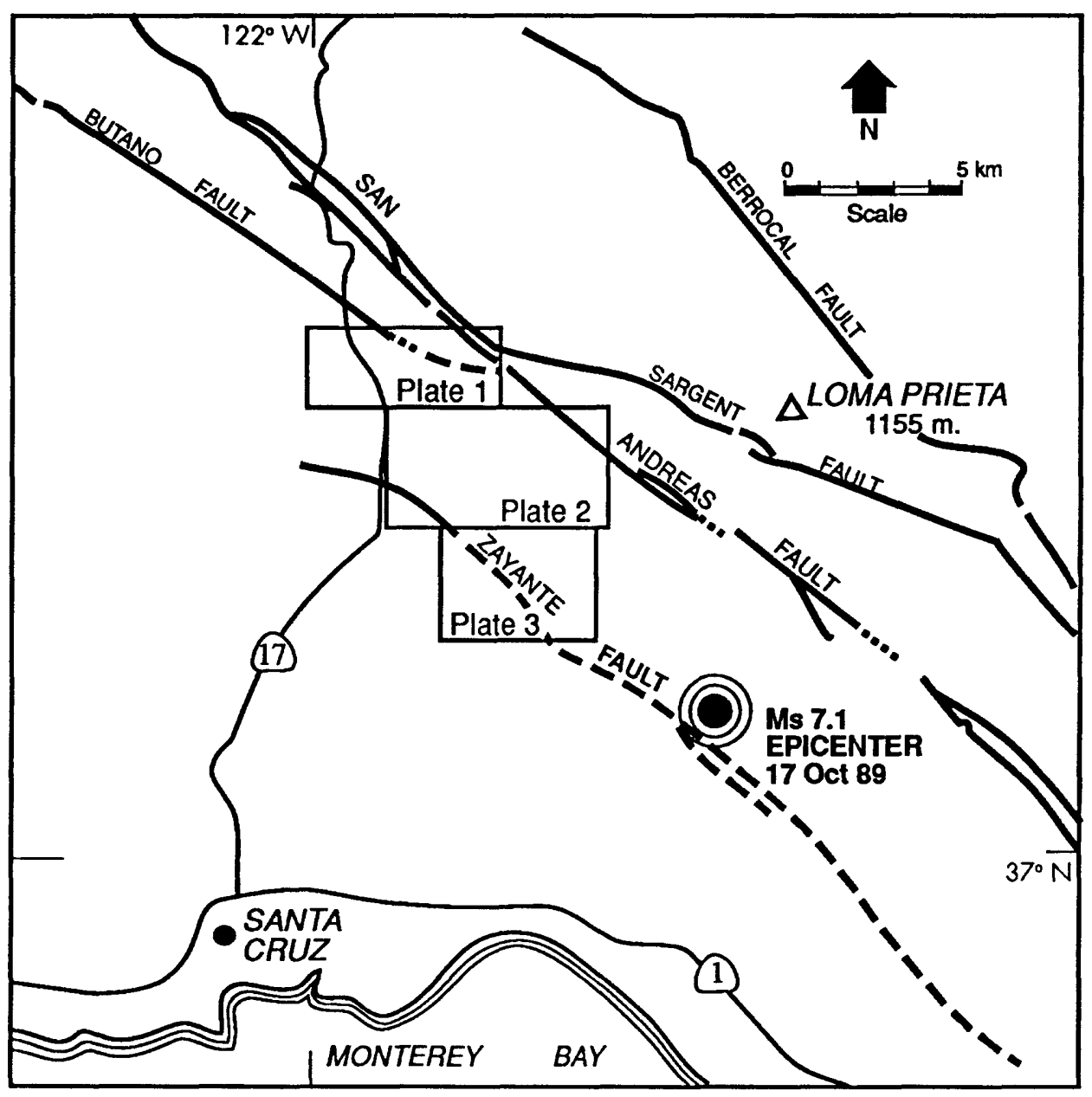

Figure 1. Location map showing regional faults, Loma Prieta earthquake epicenter, and location of plates 1, 2, and 3 where coseismic fractures and landslides were mapped. 
Appendix B

Geologic Note Code Numbers:

For field notes, their locations, and other information each geologist has a prefix identification number. These numbers are:

1 - Kit Custis - CDMG

2 - Jeff Howard - CDMG

3 - John Schlosser - CDMG

4 - Tom Spittler - CDMG

5 - Rick Lozinski - Leighton \& Assoc.

6 - Lyne Perry - Leighton \& Assoc.

7 - Bob Whitney - Leighton \& Assoc.

8 - Siang Tan - CDMG

9 - Gerry Weber \& Associates

10 - Robert Sydnor - CDMG

11 - Jerry Treiman - CDMG

12 - Nan A. Rosenbloom - UCSC

13 - Pam Irvine - CDMG

14 - Ed Harp - USGS

- Kevin Schmidt - USGS

15 - Paia Levine - County of Santa Cruz

16 - Dave Wagner - CDMG

17 - Jeff Nolan - Consultant

18 - Bill Bryant - CDMG

19 - Rich Greenwood - CDMG

20 - Ray Rice - Dames \& Moore

21 - Sally Goodin - Dames \& Moore

22 - Chris Hodley - CDMG

23 - Jane Nielson - USGS

-Mike Carr - USGS

24 - Steve Personius - USGS

- Kathy Haller - USGS

- Rex Baum - USGS

25 - Alan Bartow - USGS

26 - Ray Wells - USGS 


\section{GEOLOGIC NOTES}

1-119. N60W Fracture, 6 " wide, direction of movement S5W.

3-36. Large debris-flow chute that appears to go several hundred feet upslope.

3-40. Crack - locally tension, locally compression. Appears to be lateral margin of a landslide. Tension portion shows 6 " separation, $1 \mathrm{ft}$ - $2 \mathrm{ft}$ deep, very little vertical displacement, direction of movement $\mathrm{S} 82 \mathrm{~W}$.

3-50. Two cracks across Old Santa Cruz highway with right lateral offset of center line yellow stripes, 1 " on east crack and 3.5" on west crack. East crack is extensional with offset of 6", down to NE, cracking area is paved over, but is about $19 \mathrm{ft}$ wide. West crack is $1 \mathrm{ft}$ wide and extensional. On SE shoulder of road, NE side of crack has 3-4" of vertical displacement; on NW shoulder of road - no horizontal offset.

3-51. Cracks continue southeast-facing from road. Southwesternmost has a 7 " southeastfacing scarp, 3-4" wide with 2" right lateral offset; northeasternmost crack is 2 " wide; trend is $\mathrm{N} 55 \mathrm{~W} ; 1 \mathrm{ft}$ deep; 0-2" vertical displacement, down to northeast.

3-52. Broken redwood root establishes 6" of right lateral displacement. Trend N 56 E? Total displacement 7 1/4".

3-53. Crack trending N $66 \mathrm{~W}$. Distinctive rock in hanging wall with distinctive "mold" in footwall shows 2" right lateral displacement; 2" vertical down to northeast. Another rock

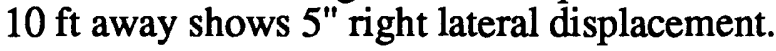

3-54. Extension crack with 6" vertical offset on northside; $2 \mathrm{ft}$ deep 3 " wide. 1" left lateral offset. Some compression locally also appears to have left lateral offset.

3-55. Extensional crack up to 2" wide; 6" deep; southwest side down with 2" vertical displacement. Elsewhere no vertical movement.

3-56. Crack 1-2" wide; 5" deep through house and planter.

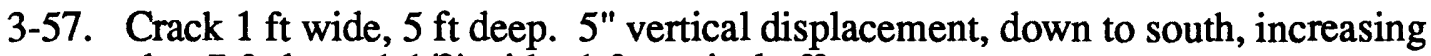
eastward to $7 \mathrm{ft}$ deep; $11 / 2$ ' wide; $1 \mathrm{ft}$ vertical offset.

3-58. Damaged house and water tank; extension cracks 4-5" wide and 4-5' deep go through house to the SE. Main scarp runs through water tank and continues SE. $2^{\prime}$ wide, 5 ' deep, $11 / 2 \mathrm{ft}$ vertical offset, down to south.

3-59. Previous crack splits into 2 cracks; northern crack is $10^{\prime}$ deep, $2^{\prime}$ wide, and has $1^{\prime}$ vertical offset. Southern crack 1' wide, 3 deep, with 6" vertical offset, down to south. Cracks $10 \mathrm{ft}$ apart.

3-60. Anastomosing cracks - extensional - $0-1^{\prime}$ vertical offset to south. $1^{\prime}$ to $3^{\prime}$ wide, 25 ' deep.

3-61. Crack 4" wide; $21 / 2$ deep; 2 " vertical displacement down to the SE.

3-62. Series of short, discontinuous, arcuate small extension cracks 1 1/2-2" wide, 1/2-2 $\mathrm{ft}$ deep. 
3-67. Several small extension cracks along SE trending ridge. Cracks 1-2" wide, 1-2 ft deep, and no vertical offset. Discontinuous, short.

3-68. Trend N $48 \mathrm{~W}$. Extension crack; open 5 3/4"; 9 1/2" vertical offset, down to southwest; 1 1/4" right lateral offset.

3-69. Crack - $1 \mathrm{ft}$ wide; $1 \mathrm{ft}$ vertical offset, down to south.

3-70. North side of Summit Rd. Reverse thrust movement of driveway and soil; up 1" to south.

3-71. Crack trends N $37 \mathrm{~W}$. Extension is 3.25" N $21 \mathrm{~W}$. 2" left lateral displacement. 2 $1 / 2$ " vertical displacement with south side up; $8 \mathrm{ft}$ deep. Extends to $S E$ under house on adjacent property - house split, with south side up 4".

3-72. 4" vertical displacement down to south; 3 " wide; $2 \mathrm{ft}$ deep, increasing northwest to $21 / 2$ " right lateral displacement; 5 " wide; $1 \mathrm{ft}$ vertical displacement down to south; $9 \mathrm{ft}$ deep.

3-73. Crack $3 \mathrm{ft}$ deep; $1 \mathrm{ft}$ wide; vertical offset down 2-4" to SE.

3-74. Trend of crack N $60 \mathrm{E} ; 6 \mathrm{ft}$ deep; 4-18" wide; vertical displacement 5-12" down to SE; lateral offset 14" in S $87 \mathrm{E}$ direction.

3-75. Crack with reverse movement in road, extends west to steep sided drainage, does not appear to extend across drainage. N $40 \mathrm{~W}$.

3-76. Anastomosing cracks, with graben. Cracks $3 "-11 / 2 \mathrm{ft}$ wide; $1-4 \mathrm{ft}$ deep; extensional. Vertical displacement on graben 2-4". Trend N $10 \mathrm{~W}$.

3-77. Small extension crack 2-4" wide; no vertical offset.

3-78. Set of small but continuous extension cracks 1-2" wide; $1 \mathrm{ft}$ deep. Trend N $68 \mathrm{~W}$.

3-79. Crack with $2 "$ reverse motion (uphill side down).

3-80. Small cracks in yard and through driveway north of house formed an area of subsidence.

3-82. Crack is 3 inches wide, 5 inches deep, no vertical offset.

3-83. Between 3-82 and 3-83, crack was obscured by leaves, etc. Must uncover it to follow it. No evidence in the creek, but crack is visible in the northwest bank. It is not traceable on the southeast bank of the creek or the slope above the creek.

3-86. Cracks in Schultheis Road are not traceable down steep NW bank of creek.

3-87. Appear to be road-fill prism failures. Cracks are in road and are associated with shattered rock, rockfall, or sloughing in roadcut.

3-88. Extensional crack; 5" wide; $21 / 2 \mathrm{ft}$ deep; vertical displacement 3", down to west.

3-89. Extension cracks 1-2" wide; 6-12" deep; short, en echelon. 
3-90. Crack extends from Schultheis Road through a garage and house. Foundation offset 1/2". Crack 1-2" wide. Little vertical offset.

3-91. Set of discontinuous, en echelon arcuate cracks. 2-12" wide; $1 \mathrm{ft}$ to $6 \mathrm{ft}$ deep; vertical offset with both uphill and downhill side down 0-4 inches.

3-100. Crack in pavement of Stagecoach Road. $2 \mathrm{ft}$ wide; 10 " deep; vertical displacement 3" down to southwest.

3-101. Crack 3"-9" wide; $5 \mathrm{ft}$ deep; vertical displacement 2", down to southwest.

3-102. Cracks in driveway and road - 1" or less wide; no vertical offset.

3-103. Crack goes through driveway. 1"-7" wide; $31 / 2 \mathrm{ft}$ deep; vertical displacement 3", down to south; left lateral displacement $5 "$ ", downslope to southeast.

3-105. Small $1 / 2$ " wide cracks, no vertical offset apparent.

3-106. 1" crack; no vertical offset.

3-107. Discontinuous 1"-wide crack, $1 / 2$ " vertical displacement, down to NE.

3-108. Series of 3 scarps; vertical offset of 2 " on all but the farthest NE. Here vertical offset was about $1-11 / 2 \mathrm{ft}$, down to northeast.

3-109. Crack 4-6" wide; $1-11 / 2 \mathrm{ft}$ deep; vertical offset down to northeast $1 / 2$ "-1" or less.

3-110. Crack 3-8" wide; $1-21 / 2 \mathrm{ft}$ deep; vertical displacement 1-5". Scarp is along margin of recently filled area.

3-111. Crack 2-3" wide; 3-4 ft deep; vertical displacement down to northeast 3".

3-112. Crack with 5" vertical displacement; 5" wide; $1 \mathrm{ft}$ deep.

3-113. Crack 1 " wide with $1 / 2$ " vertical displacement, down to northeast; $1 \mathrm{ft}$ deep.

4-101. Incipient scarp, N50E, NW side down 5", 2" extension. Fissure over 6' deep. Movement N25W

4-111. N25-30W fissure, $>300$ ' long, with minor offset. Scarp location may be influenced by fill, but crack is through rock for most of its length.

4-112. 6" high scarp across 6-8" wide fissure (4'deep). Direction of movement is S45W.

4-113. Scarp crosses small gulley.

4-117. Fracture in road N60W, roadcut failed for 40 feet as rockfalls. Arcuate scarp parallel to top of road cut. Cracks parallel to ridge 75' upslope (upslope-facing scarps).

5-3. Two major cracks separate cement divider in a right lateral sense. One fracture can be traced continually from road towards the Cloud 9 restaurant. Horizontal offset is about 
0.5 " on cement divider and about 2-3" vertical. Fractures cannot be traced west of road. Cracks are 1-2 ft deep.

5-7. 15' long crack in driveway trending N76W.

5-9. Reactivated slide.

5-10. Reactivated slide along road.

5-12. Extensive road fracturing, vertical offsets of about 8".

5-13. Cracks extending under house; fracture can be traced above road and westward to cut back across the road.

5-14. Fracture with 6-7" of vertical offset - appears to be fill failure along road margin. Tree branches broken here by shaking.

5-16. Fractures on outer edge of lot; fill failure.

5-17. Arcuate fracture showing continuous cracking for over 100'. Separation ranges from 2-3" up to 1.5'. Fissures are up to 2" deep at headscarp area. Dip slip movement varies from 1-6". Can trace fracture through damaged home, no apparent back rotation.

5-18. Fracture cuts through damaged home and heads towards Schultheis Rd.

5-19. Fracture continues through house and reappears on road below.

5-20. Headscarp of slide with rotational movement. Vertical offset of 1-1.5'. Slope below displays old landslide features. There is a mounded area below slide that probably is the toe with some overthrusting.

5-22. Fill failure.

5-28. Fill failure along road.

5-29. Fill failure.

5-30. Arcuate fractures at base of house with 2-3" separation, several cracks perpendicular to slope.

6-1. Left lateral crack on street with $11 / 2^{\prime}$ offset trending N $5 \mathrm{E}, 2^{\prime \prime}$ wide; $1 / 4^{\prime \prime}$ vertical displacement; down to east side; by mailbox at 22548 Summit Rd.

6-2. About 300' west of 6-1 at 22546 Summit Rd are cracks with 2" of right lateral offset, 1 " vertical displacement, down to east; trend $\mathrm{N} 10 \mathrm{E}$.

6-3. Crack trending N 5 E; no vertical or lateral separation, 1" wide.

6-4. Major crack (repaired in road) oriented N $10 \mathrm{~W} ; 2.5^{\prime}$ left lateral offset of curb; bends to $\mathrm{N} 35 \mathrm{~W} ; 11$ " vertical offset, down to east.

6-6. Minor discontinuous cracks trending N 60-80 W; very irregular, approximately $30^{\prime}$ long; 1.5 " wide; no lateral or vertical offset; 1 ' deep.

6-7. Small compressional crack oriented N 15 E; 20-30' long; 2" vertical displacement. 
6-8. Crack trending $\mathrm{N} 10 \mathrm{~W} ; 7^{\prime \prime}$ wide; 3 " vertical offset; 2.5 ' deep.

6-9. Crack trending N $65 \mathrm{~W} ; 2$ " wide; 2.5 ' deep; 1" vertical offset, down to southwest.

6-11. Crack trending N-S; 8" deep; 1 " wide; 15 ' long; minimal cracking in pool decking overlying crack; 17516 Old Summit Rd. - well OK.

6-12. Crack trending N $50 \mathrm{~W} ; 3$ " vertical displacement, 2" wide; 4" deep.

6-13. Crack trending $\mathrm{N} 35 \mathrm{~W} ; 1$ " vertical displacement, down to northeast.

6-14. Crack trending N $40 \mathrm{~W}$; 6" vertical displacement; 4" wide; 15" deep; N $65 \mathrm{E}$ displacement vector.

6-15. Crack trending N $40 \mathrm{~W} ; 1-8$ " wide; $2-8$ " vertical displacement, $12 "$ deep; $\mathrm{N} 70 \mathrm{E}$ displacement vector.

6-119. N $85 \mathrm{E}$ hairline crack between corner of barn and house at 17430 Old Summit Rd. Well 140' deep; some silt, but OK. 22616 Summit Rd.

6-121. Crack trending N $15 \mathrm{~W}$; 1' vertical displacement; 8" wide; 3" deep; parallels Summit Rd. approx. 10' down slope.

6-122. N $50 \mathrm{~W}$ compressional fracture with 1" vertical displacement. 1/4" wide.

6-123. Crack trending $\mathrm{N} 20 \mathrm{~W}$ with $1 / 2$ " right lateral offset; 1 " wide.

6-124. N $80 \mathrm{~W}$ - crack; 2" vertical offset; 1" wide; 1' deep; 30' long; 1" left lateral displacement.

6-125. Crack trending N 80 E; 2" separation; 10 " deep; no vertical or horizontal displacement; bends to $\mathrm{N} 55 \mathrm{E}$.

6-126. Crack trending N 60 E; 6" wide; 7" deep; 5" lateral displacement to N15W.

6-127. Crack trending N60E; compressional feature?? with a N $20 \mathrm{~W}$ direction of movement; 1" vertical displacement; crack dies out on slope 20' above brown water tank.

6-128. Crack oriented N 80 E., 1/2" wide; $1 / 4$ " vertical displacement, up to the southeast.

6-129. Left lateral crack trending $\mathrm{N} 35 \mathrm{~W} ; 2.5^{\prime}$ of movement to $\mathrm{N} 30 \mathrm{~W} ; 4-12$ " vertical displacement; up to 13 " wide; 21 " deep.

6-130. Crack trending N $35 \mathrm{~W} ; 6$ " vertical displacement down to southwest; 8" left lateral direction of movement to $\mathrm{N} 15 \mathrm{~W}$. 6-131. Failure along dirt road; direction of movement N 55 E, down to northeast; 6" vertical displacement; 9" deep; 3" wide.

6-132. Crack trending $\mathrm{N} 35 \mathrm{~W}$ with direction of movement $\mathrm{N} 70 \mathrm{E}$; 10 " vertical displacement, down to southwest; 8" wide; 2' deep.

6-133. $\mathrm{N} 45 \mathrm{~W}$ - trending crack above near vertical cut slope; $1-12$ " vertical displacement generally down to southeast; $0-7$ " wide. 
6-134. Crack trending $\mathrm{N} 30 \mathrm{~W} ; 2-8$ " wide; 20 " deep; part of crack appears to occur along a cut/fill contact.

6-135. Crack trending $\mathrm{N} 35 \mathrm{~W} ; 1.5^{\prime}$ deep; $2-12^{\prime \prime}$ wide; 1 " vertical displacement up to northeast; direction of movement is $\mathbf{S} 70 \mathrm{~W}$, downslope.

6-136. Crack trending N $55 \mathrm{~W} ; 1$ " wide; 2 " deep; 1 " vertical displacement, up to NE; direction of movement $\mathrm{N} 20 \mathrm{E}$.

6-137. Several compressional and extensional subparallel cracks trending N $10 \mathrm{~W} ; 2-3$ " vertical displacement; $0-3$ " wide; up to 1.5 ' deep; variable direction of movement. Variable sense of vertical displacement on crack.

6-138. North side of concrete road is up 1-2" relative to asphaltic concrete. South side is up 0-1" relative to asphaltic concrete. Crack up to 1 " wide and 2" deep. Numerous perpendicular cracks in old Santa Cruz Hwy. Approx. 1/4-1/2" left lateral offset of centerline.

6-139. Compression of asphaltic concrete side over concrete road; asphaltic concrete thrust up to $6 "$ over concrete.

6-140. N 75 W-trending hairline crack.

6-141. Numerous, small slumps, rockfalls and perpendicular fractures across road.

6-142. Apparent old landslide judging from topographic expression and change in vegetation.

6-143. Crack trending N $50 \mathrm{~W} ; 3^{\prime \prime}$ vertical displacement, up to northeast; $1-3$ " wide; 4.5' deep; direction of movement $\mathrm{N} 40 \mathrm{E}$.

6-144. Irregular crack trending $\mathrm{N} 70 \mathrm{~W} ; 1-8$ " wide; $5.5^{\prime}$ deep; $1-2$ " vertical displacement with both senses of vertical movement along the crack. Direction of movement N $50 \mathrm{E}$.

6-145. Numerous small discontinuous cracks trending generally $\mathrm{N} 30 \mathrm{~W}$.

6-146. N $40 \mathrm{~W}$-trending irregular crack; $1 / 4-1 / 2$ " wide; $2-3$ " deep with no horizontal or vertical offset.

6-147. Crack trending $\mathrm{N} 60 \mathrm{~W} ; 3.5^{\prime}$ deep; $1^{\prime}$ wide; $4-5^{\prime \prime}$ vertical displacement, down to $\mathrm{SE}$; direction of movement $\mathrm{N} 40 \mathrm{E}$.

6-148. Partially filled extension cracks trending N $35 \mathrm{~W}$ across dirt/gravel drive way; 1-2" wide; one extends beneath barn.

6-149. $\mathrm{N} 70-75 \mathrm{~W}$ - trending extension and compression cracks; up to 1 " vertical displacement, down to southwest; 2" deep; 1-2" wide.

6-150. N $60 \mathrm{~W}$-trending - extension crack; 1' deep; 1-2" wide; up to 8" vertical displacement down to SW; slight right lateral movement to $\mathrm{E}$.

6-153. Repaired crack trending $\mathrm{N} 30 \mathrm{~W}$ in road; extends into soil on both sides of road. 
6-155. Crack trending N $75 \mathrm{~W}$; extends beneath SE corner of house; 1-8" vertical displacement; 1/2-4" wide; 5 ' deep at corner of house; 1 ' deep average; direction of movement $\mathrm{N} 40 \mathrm{E}$ to $\mathrm{N} 10 \mathrm{E}$.

6-157. Crack trending $\mathrm{N} 60 \mathrm{~W} ; 1^{\prime}$ deep; 1 " wide; 3 " left lateral movement to $\mathrm{S} 70 \mathrm{~W}$ direction.

6-158. N 45-65 W - trending cracks in fill or at cut-fill boundary; 3.5' deep; direction of movement N $40 \mathrm{E} ; 3$ " to 2' wide. Rotation of failure at top of fill slope.

6-159. Compressional crack across driveway trending N $65 \mathrm{E}$; up to southeast, vertical displacement is about $2 "$.

6-160. Old slump failures along driveway.

6-161. Crack trending N $40 \mathrm{~W} ; 2^{\prime}$ deep; 1-3" vertical displacement, up to southwest; 1-4' wide.

6-162. N-S-trending crack, locally compressional; 1-2" vertical displacement; direction of movement $\mathrm{N} 50 \mathrm{~W}$; extends beside swimming pool; displaced concrete up and down on west side; up to $2.5^{\prime}$ deep and $4^{\prime \prime}$ wide.

6-165. Crack trending N 80 E; 2" vertical displacement; 4-5 deep.

6-167. Crack trending E-W; 8-12" wide; 1-2" vertical displacement; direction of movement to the south; $30^{\prime}$ long, not continuous.

6-168. Crack trending N $60 \mathrm{~W} ; 3^{\prime \prime}$ deep; 1-3" wide; 2" left lateral offset; $1 / 2^{\prime \prime}$ vertical displacement, down to $\mathrm{SW}$.

6-169. Small slide/slump; 8-10" wide; 2-3' deep; 8" high head scarp; slight compressional features at toe of slide on dirt path/road.

6-170. Crack trending $\mathrm{N} 80 \mathrm{~W} ; 2^{\prime \prime}$ deep; 1 " wide; $1 / 2$ " vertical displacement with sense of displacement variable.

6-171. Crack trending N $80 \mathrm{~W}$; 1" wide; 4" deep; 1" vertical displacement, down to southwest; 2" right lateral offset; direction of movement $S 80 \mathrm{~W}$.

6-172. Crack trending $\mathrm{N} 65 \mathrm{~W}$ to $\mathrm{N} 55 \mathrm{~W}$; several subparallel cracks; $1 / 2-4$ " vertical displacement, down to SW; 1' deep; 1-8" wide; left lateral offset; direction of movement $\mathrm{N}$ $30 \mathrm{E}$.

6-173. Slump/slide; hummocky topography.

6-174. Crack trending N $20 \mathrm{~W}$; 8-12" vertical displacement; width 1-10"; large cracks in driveway in every direction. A section of driveway appears to be moving downslope into adjacent stream canyon.

7-1. Rolls Rd. Tension cracks across road. Trend N87W. Tension direction N3E. Can be traced to bank on east side of road when it becomes disseminated west of road. Traces downhill with N82E trend. Intersects graben feature about 120' from road.

7-2. Tensional crack system, down to SE. 
7-3. Top broken out of 1' diameter oak tree.

7-4. Crack open; 14-16" vertical displacement, south side down. Trend N86E; at 7'depth crack still open as much as $1 "$. Roots indicate $10^{\prime \prime}$ right lateral displacement. Total slip from root tips is $231 / 2$ ".

7-5. Tension crack open as much as 1'; trends N43W; dies out to NW. No vertical component. Does not affect cement driveway to $\mathrm{SE}$ of road.

7-6. Tension crack along road. Dies off to NW in road. Dies off to SE after turning off road. Trend N62W. Looks like head of small slump. No lateral shears. May be road-fill failure.

7-8. Tension crack up to $15^{\prime \prime}$ wide, generally about 7" wide; up to 6' deep. Trend N38W; vertical displacement as great as 6", down to SW. Roots show offset of 11 " total displacement; about 5" vertical displacement, 8" extension and 4" left lateral.

7-9. Extension fracture with trend of N30W.

7-10. Tension crack. Open as much as 6". 2" vertical offset, SW down. No apparent lateral displacement. Crack is up to $12^{\prime}$ deep. Stops downhill at property line in 3 en echelon breaks.

7-11. Tension crack open to as much as 12 " with about 2 " vertical displacement. Up to 6 ' deep; dips $70^{\circ}$ to NE. Near property line en echelon pattern ends; sinuous pattern with general trend of N15W. 120' SE of property line, fracture still dipping to NE; up to 8" vertical displacement with an average of about 2"; up to 16 " extension with an average of about 8".

7-12. Tension cracks open 3 to 8". Trend NS. 0-6" vertical displacement (east side down). Crack open to $5 \mathrm{ft}$ depth.

7-13. En echelon cracks up to 3' long; spaced about 1' apart; 1" extension in center. Right stepping. Property owner reported cracks formed from south to north during shaking.

7-15. Tension crack open 1-2". No vertical displacement. 1/2" open crack $28^{\prime}$ inside property line across driveway. 1 " open crack about 6.5 ' inside property lines across driveway. Trend $\mathrm{N} 45 \mathrm{~W}$. Vertical displacement $0^{\prime \prime}$ to $2^{\prime \prime}, \mathrm{NE}$ side down. Tension crack about $175^{\prime}$ from property line in driveway. Trend N32W. 2" -4 " vertical displacement, NE down. No apparent lateral offset.

7-16. Tension crack open up to 5". Some graben formation with downdropped blocks having up to 14" vertical displacement. Overall vertical displacement is about 4", NE side down. About 3" left lateral displacement with N32W-trend.

7-17. 4" vertical offset, NE side down.

8-1. Extensional fissure about $1 / 2$ " wide.

8-2. N-S strike, about 2" down to west.

8-3. 3 main fractures in zones trending E-W and 120' long. Fissures are up to 4" wide. 8-4. 1" wide, open fissures. 
8-6. Irregular, sinuous soil fissures, N40W, up to 2 " wide within zone of $100^{\prime}$ length.

8-7. Series of fractures in soil within a $15^{\prime}$ wide zone trending N30 W and more than $250^{\prime}$ long. Vertical displacement up to 2", with sense of displacement variable. Fractures are sinuous and irregular.

8-8. Small fissures in soil; irregular, up to $50^{\prime}$ long.

8-9. Possibly compression fractures, minor bumps, in asphalt pavement of Old Summit Rd.

8 -10. Fracture striking N60W, with northern side down about $11 / 2$ "; up to $11 / 2^{\text {" wide. }}$ This fracture may be related to fill settlement during seismic shaking; some portions of fissure existed prior to the earthquake.

8-11. 15' wide zone of E-W trending irregular, open fissures in soil--some are up to 4" wide.

8-12. N30W fissure in driveway and soil; 3 " wide in soil, 2 " wide in asphalt pavement. 8-13. E-W-trending open fissures within a 30' wide zone, continuation of 8-11. Most fractures are down to south side up to 7"; up to 5" wide.

8-14. Fracture across Summit Rd. at intersection with Old Summit Road; N10W, 1" wide; $1 / 2$ " down to east upslope.

8-15. Fracture across Summit Rd. trending N30W, 2" wide, right lateral displacement $1 / 2$ "; also many other smaller fractures.

8-16. Fracture across Summit Rd.; 2 open fractures up to 1" wide.

8-17. 4 open fissures; sinuous; each $1 / 2$ " wide.

8-18. Fracture trending N30E, up to $1 "$ wide.

8-19. 2" wide fracture; $1 / 2$ " down to northwest; sinuous. 5 other smaller fractures.

8-20. Fissure N45E, 2" wide.

8-21. Fissure trending N50E; 3 " wide, 2 " vertical displacement; may be related to roadfill settlement.

8-22. 2 fissures, $1 / 2$ " and 2" wide. May be related to road-fill settlement.

8-23. Fracture 1 " wide, $1 / 4$ " down to southeast. To the east, 3 small fractures, the 2 larger have 2 " right lateral displacement.

8-24. Discontinuous series of fractures generally trending N75E, up to 1 " wide.

8-25. Irregular fractures; may be related to building pad fill settlement.

8-26. Near 17774 Old Summit Rd., part of the asphalt pavement seems to be thrust over another part of the street above a subdrain. Fracture trending east-west, south side over north about $6 "$. 
8-27. $31 / 2$ " wide east-west fissure; may represent the "pull-away" area of the activated landslide to the south.

8-28. Headscarp of active landslide; fissures trending N20W; 50' wide zone of fracturing, up to 6 " vertical offset. Cracked resurfaced driveway indicates recurrence of landslide movement.

8-29. Fissures at upper edge of landslide, trend about N35W; up to 1' vertical displacement, down to the southwest. Headscarp fissures are up to 5 " wide.

8-30. Small fissures at a possible headscarp of landslide.

8-36. A set of 2 fractures trending N30W; about 2" wide; 1 " vertical displacement, down to east; 1 " left lateral displacement.

8-37. Series of fractures about 1 " to 2 " wide; up to 1' vertical drop; headscarp of activated landslide.

8-38. 2" to 3" left lateral displacement on a 2" wide fracture in asphalt road, part of upper edge of landslide at 8-37.

8-39. Fracture trending about N10W, open up to 3 "; vertical displacement $1 / 2$ ", down to west.

8 -41. Irregular open fissure; may be related to road fill failure. 1 " to $2 "$ right lateral displacement; about 4" wide; trend N50E.

8-42. Up to 1'-wide fissures in fill.

8-43. Several east-west trending fissures, about 2" wide; may be related to fill failure.

8-44. Fracture along the outer edge of curve of concrete pavement of Old Santa Cruz Rd. affecting the road fill; about 6 " wide. It may be purely a shaking effect.

8-45. Fracture through concrete pavement of Old Santa Cruz Rd. with a 9 1/2" right lateral offset. Some evidence of modified scarps found.

8-46. Open fissure up to $4 "$ wide trending N15W, may be continuation of fracture at 8-39.

8-47. Several fractures trending N65W in fill. The main fracture is displaced downward to the east about $2 "$.

8-48. Headscarp fractures, consists of series of open fissures up to $1 / 2^{\prime}$ wide. Most have vertical displacements down to the south of up to $1^{\prime}$. The fissures form a zone about $10^{\prime}$ wide.

8-49. Eastern edge of landslide; $40^{\prime}$ wide zone of many small fissures with up to $1 / 2^{\prime \prime}$ vertical offset.

8-50. Fractures cracked concrete floor and foundation at 27467 Majestic Drive. Fissures south of residence up to 3 " wide; $11 / 2$ " vertical displacement. Fissures in concrete floor up to 2 " wide.

8-51. 2 main fissures up to 2 " wide on western edge of landslide. 
8-52. Several open fissures with up to 6 " vertical offset on western headscarp.

8-53. 3 main fissures within a zone of $20^{\prime}$ at western boundary of slide. Fractures up to 1 ' wide; vertical displacement up to $1 \mathrm{ft}$.

8-55. 3 open fissures through tennis court; up to 2 " wide.

8-57. Fracture trending N20W; down to NE 2", 2" wide.

8-60. Fracture trending N40E, down $1 / 2 "$ to west; about 2" wide.

8-61. Fracture; east side down about 1/2"; N-S-trending.

8-62. Fractures across asphalt are $11 / 2 "$ wide with $2 "$ right lateral displacement.

8-63. Dirt-filled fractures in driveway and through foundation, trend roughly N-S.

8-64. Minor ground failures about 1 " wide; 50 ' long; trending NE.

8-66. Large open fissures along gully with water seepage; up to $1 / 2$ wide; $\mathrm{N}-\mathrm{S}$ to $\mathrm{N} 20 \mathrm{~W}$ trending.

8-67. 4 fractures in asphalt.

8-68. At least 3 subparallel NW trending fissures through building pad; about $2 "$ wide.

8-69. Fissures at headscarp of major landslide; $1 / 2^{\prime}$ wide; $1 / 2^{\prime}$ vertical displacement. Zone of fracturing up to about 100 ' wide, resembling "ploughed ground."

8-70. Open large fissures across asphalt trending N15W and N10E, up to 1' wide with $1 / 2^{\prime}$ vertical offset. Sinuous, irregular; some fissures at least 7' deep.

8-72. Many headscarp fissures along road up to 1 ' wide.

8-75. N65W-trending fracture in asphalt driveway continues into adjacent ground; up to $1 / 2$ " wide; may be related to fill failure.

8-76. Irregular fractures trending NW in asphalt, up to 1 " wide. Fissures occur in pavement and do not continue into adjacent ground surfaces.

8-78. Large fractures; vertical displacement up to $1 / 2$ '; width up to $1 / 2$ '; may be part of an activated headscarp of a large landslide.

8-79. Fissure about 3 " wide; may be fill failure.

8-80. Large reactivated landslide on Redwood Lodge Rd.; previous headscarp over 10' high. No big trees found on landslide, which may indicate previous movement. Toe shows downslope movements, creeping soil and shallow landslides.

8-81. N30W-trending large fracture may be partly related to failure of fill.

8-82. Several fissures up to $1 / 2^{\prime}$ wide.

8-83. Fissures at headscarp up to $1^{\prime}$ wide; downslope displacement up to $11 / 2$ '. 
8-84. N30W-trending zone of many fractures up to 4 " wide.

8-86. Several fissures; downslope displacement about 3".

8-90. Numerous N15-20W-trending fissures; includes "ploughed ground" within a more than $40^{\prime}$-wide zone. Width of fissures up to $3 "$ with vertical offset up to 2". Minor graben in center of fracturing may be part of uphill-facing scarp of reactivated landslide.

8-91. Several fissures within a $100^{\prime}$ wide zone; vertical offset up to 2 ', with extension up to $6 "$.

8-92. 200'-wide zone (continuation of 8-91) trending N25W of extensional fissures up to 6 " wide; affects building pad, fill, and foundation.

8-93. Several fractures trending different directions. Individual fissures up to 4 " wide.

8-100. Open fissures up to 2 ' wide with 1.5 ' down-slope displacement. The lower portion of the landslide seems to be also activated.

8-101. N40W trending, 1' wide fissure is part of an extensive fracture zone.

8-103. Several 4" wide fissures trending N30W.

8-104. N25W-trending fracture has 3 " vertical displacement. ??

11-1. Left-stepping fissures: N60-65W trend of zone 2"-4" wide; no scarp; extensional; up to $3^{\prime}$ deep.

11-2. N80W fissure approximately $31 / 2$ '-4' deep; 6-8" to 10 " wide; $2-3$ " vertical displacement, down to $S$. Zone trends $\mathrm{N} 65 \mathrm{~W}$; roots stretched across crack indicate extension.

11-3. Approximately 10 '-wide zone of arcuate fissures.

11-4. Fissure: N70W; uphill-facing 6" scarp; open approx. 3".

11-5. Irregular fissure trends approximately $\mathrm{N} 25 \mathrm{~W}$.

11-6/7. Numerous short right-stepping fissures trend N85E.

11-8. Landslide with graben approximately 3 ' wide and 4 ' deep; $90^{\prime}$ from road; scarp up to 4 ' high; 5 major fissures roughly evenly spaced between road and graben; fissures up to 6' deep.

11-11. Margin of cracking at top of old scarp; projects to highway marker 7.9.

11-12. Cracks in Soquel San Jose Rd.: approximately 6" right lateral displacement on one crack near north edge of fill with $30^{\prime}$-long mole track.

11-13. Probably old landslide scarp is breaking headward to projection of N65W fissure zone; scarps up to $2^{\prime}$ high on some fissures; graben up to $8^{\prime}$ wide within interior block; 34 ' wide fissure. 
11-18. 12"-18"-wide fissure; trends N65W; fissures above old scarp; several larger fissures all approximately $2^{\prime}$ deep, up to $3^{\prime}$ deep further down slope.

11-27. Incipient failure above highway road cut; fissure 2-2 1/2' deep; 10-12" wide; numerous other fissures all over ridge.

11-28. Fissure $21 / 2^{\prime}-3^{\prime}$ deep; up to $8^{\prime \prime}$ wide; approximately $10^{\prime}$ back from slope face.

11-30. Ridge-shaking cracks.

11-31. Cumulative displacement of $3 "-5$ " extension and 2"-3" down to southwest; trend N70E.

11-45. Fissure at head of old landslide up to 18 " wide, 18 " high; probable sliver failure of old scarp.

11-47. Steep bluff rockfall across creek.

11-48. 3 fracture sets. One approximately N30E, left stepping; approximately N80W

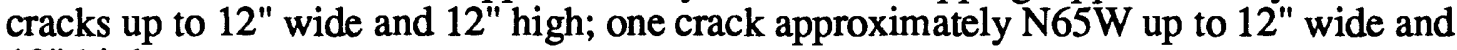
12 " high.

11-49.Approximately N70W fracture zone (up to 4 " wide) may bound southwest-moving landslide below house; tension cracks below up to 18 " wide, 12" high.

11-53. Fissure on knob, open approximately 8".

11-54. Creek dammed by landslide.

14-1. Crack trending N $50 \mathrm{~W} ; 3.5 \mathrm{~cm}$ left lateral displacement; $3.5 \mathrm{~cm}$ vertical displacement; up to southwest.

14-2. Crack with $2 \mathrm{~cm}$ extension; $2.5 \mathrm{~cm}$ vertical displacement.

14-3. About $20 \mathrm{~cm}$. left lateral displacement.

14-4. About $30 \mathrm{~cm}$. left lateral displacement.

14-5. About $6 \mathrm{~cm}$ extension; $3 \mathrm{~cm}$ left lateral displacement.

14-6. $64 \mathrm{~cm}$ vertical displacement on slide scarp; about $30 \mathrm{~cm}$ horizontal displacement.

14-7. About $7 \mathrm{~cm}$ horizontal displacement and about $6 \mathrm{~cm}$ vertical displacement on the farthest upslope scarp. Crack continues upslope N55W behind green house with $5 \mathrm{~cm}$ of left lateral displacement; $2-3 \mathrm{~cm}$ extension.

14-8. $9 \mathrm{~cm}$ vertical displacement; $9 \mathrm{~cm}$ extension; up to west; trend $\mathrm{N} 60 \mathrm{~W}$.

14-10. About $3 \mathrm{~cm}$ vertical displacement, up to west.

14-11. Reactivation of an old slide with the present cracks along the headscarp revealing several decimeters of vertical displacement; situated downslope from a cliff which is a preexisting headscarp. From the crown to $50 \mathrm{~m}$ downslope, the right lateral margin (looking downslope, southwest) shows $23 \mathrm{~cm}$ of extension and $15 \mathrm{~cm}$ of vertical 
dsiplacement. This purely extensional portion trends east-west. The right lateral margin, just over $50 \mathrm{~m}$ from the headscarp, has a N70E trend with $15 \mathrm{~cm}$ of right lateral and $23 \mathrm{~cm}$ of extensional displacement. The right margin continues with $30 \mathrm{~cm}$ of right lateral displacement, but the trend shifts to N50E, and the landslide block is upthrust here. A compressional tent is also present as the margin bends toward the axis of the slide.

14-12. Fissure with left-lateral displacement of approximately $8 \mathrm{~cm}$ and $8 \mathrm{~cm}$ of extension. Trend N40W.

14-13. Fissure in pony pen adjacent to Loma Prieta Church: Left-lateral displacement of approximately $3 \mathrm{~cm}$. The fissure emanates from the southeast corner of the church where bulding is damaged and continues through pony pen toward a backfilled sag pond several meters in diameter. Homeowner filled in sag with debris; sag feature is pre-quake.

14-14. $18 \mathrm{~cm}$ vertical displacement; $5 \mathrm{~cm}$ right lateral displacement; up to north.

14-15. 14 to $16 \mathrm{~cm}$ horizontal offset. Looks like a landslide scarp.

14-16. $12 \mathrm{~cm}$ horizontal displacement, $7 \mathrm{~cm}$ vertical displacement, down to southwest.

14-17. $6 \mathrm{~cm}$ horizontal extension, $8 \mathrm{~cm}$ vertical displacement, up to southwest.

14-18. $7 \mathrm{~cm}$ left lateral displacement; $6 \mathrm{~cm}$ vertical displacement; southwest side up.

14-19. $10 \mathrm{~cm}$ extension; $6 \mathrm{~cm}$ vertical displacement; slump.

14-20. $20 \mathrm{~cm}$ extension; pre-existing slump.

14-21. $22 \mathrm{~cm}$ vertical displacement; $8 \mathrm{~cm}$ extension; slump into creek; other cracks show up to 1 ' extension and slumping.

14-22. $24 \mathrm{~cm}$ extension; $15 \mathrm{~cm}$ vertical displacement, down to southwest.

14-23. $15-20 \mathrm{~cm}$ extension; variable sense of vertical displacement. At break in slope looks like old slide scarp.

14-24. Extensive fissure zone on crest of linear hill trending E-W. $23 \mathrm{~cm}$ vertical displacement on north side of graben. $16 \mathrm{~cm}$ vertical displacement on south side of graben. 43-50 cm extension.

14-26. $9.0 \mathrm{~cm}$ vertical displacement; $4 \mathrm{~cm}$ extension; up to southwest.

16-2. Extension cracks trending $\mathrm{N} 80 \mathrm{~W}$ dip steeply to south. Several with $1-4$ in. displacement. They occur in soil and road fill. Down the road there are cracks in bedrock with $1.5^{\prime \prime}$ displacements.

16-3. 15996 Comstock Mill Rd. House severely damaged. Cracks trend across site about $\mathrm{N} 70 \mathrm{~W}$. They are subparallel fissures that do not extend beyond the hill on which the house sits. Most of them seem to show movement toward the free faces of the hill. Vertical displacements are of several inches to more than a foot. Horizontal displacements are about the same. The hill on which may be graded fill may have been intensely shaken because of topographic amplification of seismic energy. The intense fissure development occurs only on the house site. 
16-4A. Head wall scarp of a major landslide. Many preexisting arcuate scarps, hummocky topography and tilted, mature redwood trees indicate previous movement. Displacement during quake was a few inches to more than a foot. A home on the slide showed little or no damage.

16-4B. Fracture trends N $60 \mathrm{E}$ across meadow; follows break in slope. Horizontal separation 1"-18"; vertical separation 1 to 18"; direction of movement S $35 \mathrm{E}$. Across meadow trend changes to $\mathrm{N} 70-80 \mathrm{~W}$. Headwall scarp gives way to zone of extensional cracking that tends to be en echelon with cracks trending N50-75W.

16-4C. Farther along this trend; fractures are en echelon and follow the "old grade" of Comstock Mill Rd.

16-10. Diffuse fractures trending N50-60W. 0.5 to 3" separation toward the SE. Second set of fractures trend about N $15 \mathrm{E}$ with a maximum of 1 " separation toward SE.

18-6. Fractures trending N55W to N75-80W; generally follow free-face. Fractures have up to 5 " vertical displacement, north side down, with extensional openings to 6".

18-7. Sixty foot-wide zone of subparallel fractures; one up to 18" wide; trending N20$25 \mathrm{~W}$.

18-9. Patched crack across Skyland Rd. Extension up to 18"; vertical displacement up to 4", down to NE; up to 4 feet deep.

18-10. Fracture zone trends N50W; extensional opening to 8" (may be enlarged by slumping into fissure); can be traced for $45^{\prime}$ from road into orchard. Direction of extension $\mathrm{N} 40 \mathrm{E}$ north of road; changes to N35W south of road; parallel to slope.

18-12. 8- to 12-inch high, west-facing scarp trending N25E. Fracture up to 18" wide and trend N70W.?

18-15. Fissure north of Skyland Dr. up to 18 " wide and 7 feet deep with up to 5" vertical displacement, northeast side down.

18-16. Fissures with $2 "$ to $5 "$ vertical displacement, down to the northwest, and N10W extension up to 3"; crack follows headscarp of old landslide.

18-17. N30W fissure, 3"-4" vertical displacement, down to the northeast, 5 " maximum entension; crudely right stepping. Extension to N45E.

18-19. Fissure with up to 8" vertical displacement, Extension up to 4"; movement approximately $\mathrm{N} 40 \mathrm{E}$.

18-20. Two sets of fissures approximately 240 feet apart trending N75E. Southern set with extension up to $3 " ; 1.5^{\prime}$ to 2 ' deep. Northern fissure has extension up to $18^{\prime \prime},>4$ ' deep. Vertical displacement locally about $2 "$ to $3 "$.

18-21. N65W right-stepping fissure zone with extension up to $12 "$. Openings enlarged by sidewall slumping.

18-22. N50W fissure changes trend to N-S south of creek. Vertical displacement and extension up to 12". Fissures up to 6 ' deep. 
18-34. Twenty-inch wide, at least 3' deep fissure trends N80W from Stetson Road. Resident reported major fissure across Stetson Road that had been repaired prior November 22.

18-36. N85W - trending fissure with extension of up to 12 " and no vertical displacement can be traced downslope in a series of left-stepping fractures generally oriented N45E where fissures join with those described in 18-34. Just east of Stetson Road three subparallel arcuate fissures up to $2 '$ wide and 4' deep are within a zone about 30 feet wide.

19-1. Cracks trend N45W; up to 5" vertical displacement, northeast side down; up to 6" separation; cracks over $3 \mathrm{ft}$. deep, cracks continuous for more than 100 feet.

19-2. Cracks continue for more than $100 \mathrm{ft}$. in zone approximately $10 \mathrm{ft}$. wide containing approximately 3 cracks 2 " wide, northeast side down and apparent left lateral displacement of approximately 3 ". Cracks right stepping.

19-3. Cracks with approximately 3 " extension; N75E; northwest side down approximately $31 / 2$ ".

19-4. Apparent closed depression: Trend of cracks N85E; north side down approx. 2".

20-6. Approximately 15 cracks cross pavement.

20-8. N25W scarp; 6" displacement.

23-1. En echelon cracks trending N30W to N65W; 4 to $9 \mathrm{~mm}$ separation.

23-2. Slumping of road fill near culvert.

23-5. Crack trending N10W; opening $20 \mathrm{~mm}$; offset $20 \mathrm{~mm}$, left lateral.

23-6. Crack system about $100 \mathrm{ft}$ long. Some cracks have vertical displacements as much as $40 \mathrm{~mm}$ down to north; at SE end of system, vertical displacement is as much as $20 \mathrm{~mm}$ down to south.

23-7. In orchard, small to large en-echelon cracks trending $\mathrm{N}$ to $\mathrm{N} 35 \mathrm{~W}$; largest crack is $100 \mathrm{~mm}$ wide; no indication of lateral or vertical offset.

23-8. Cracks with $135 \mathrm{~mm}$ vertical displacement down to north; $60 \mathrm{~cm}$ deep; trend N75W.

23-9. Crack trending N50W; 28 feet long; separation 30 to $250 \mathrm{~cm}$; no indications of lateral offset. Vertical offsets range from 0 to several $\mathrm{mm}$.

23-10. Crack trending N55W ends at tributary to creek - southwest side appears to be up.

23-11. 3-30 mm extension; $35 \mathrm{~mm}$ vertical offset, down to $\mathrm{SW}$.

23-12. N80-85E fissure with $80-90 \mathrm{~mm}$ horizontal separation; $20 \mathrm{~mm}$ to $80 \mathrm{~mm}$ vertical offset, up to SW.

23-13. Cracks with N55-65W orientation, accompanied by large cracked and hummocky zone ("mole track"). About $14 \mathrm{~cm}$ vertical displacement, down to $S W ; 65 \mathrm{~cm}$ wide. 
23-14. 20'-wide zone of cracks with azimuths varying between $\mathrm{N} 65 \mathrm{~W}$ and N80W; vertical offsets up to $11 \mathrm{~cm}$ with sense variable, extensions up to $19 \mathrm{~cm} ; 1.5 \mathrm{~m}$ maximum depth.

23-15. Large scarps occur below steep slope west of house. Sense of vertical displacement changes along strike from down to SW to down to NE. Vertical offsets up to $23 \mathrm{~cm}$; small horsts and graben present surrounded by anastomosing cracks. Horizontal opening up to $180 \mathrm{~mm}$; about $2 \mathrm{~m}$ deep.

23-16. Cracks in earth road trend N65W; opening as much as $40 \mathrm{~cm}$; vertical separation 2$5 \mathrm{~cm}$; depth of crack $1.4 \mathrm{~m}$; appears to follow old scarp.

23-17. Cracks N55W to N75W; $40 \mathrm{~mm}$ vertical offset, down to northeast.

23-18. About 3-4 m-wide zone of cracks cross road. Widest fissure $2 \mathrm{~m}$ wide with keystone block collapsed within fissure $2 \mathrm{~m}$ deep; vertical separation $30 \mathrm{~cm}$.

23-19. Large crack with numerous anastomozing cracks and subsided blocks trend N45W; horizontal separation $50 \mathrm{~mm}$; vertical displacement $110 \mathrm{~mm}$, down to northeast.

23-21. Graben within crack zone trending N60W; graben $4 \mathrm{~m}$ long, $60 \mathrm{~cm}$ wide; vertical offset on northeast margin $25 \mathrm{~cm}$, southwest margin $30 \mathrm{~cm}$.

23-22. Graben features - N50W trend.

23-23. 3 small cracks trending E-W.

23-24. Fissures trending N40E to N05E; fence on Morrell Cutoff Road offset in right lateral sense, could be landslide.

23-25. N5E-trending cracks with north side down.

23-26. Crack trending N45E; horizontal displacement $150 \mathrm{~mm}$; vertical displacement 120 $\mathrm{mm}$, down to southeast.

23-27. N55-60E-trending headscarp intersects N45W trending fracture.

23-28. N70E-trending crack with horizontal displacement of $150 \mathrm{~mm}$ and vertical displacement of over $200 \mathrm{~mm}$.

23-29. N20E to N40E en echelon cracks with $10 \mathrm{~cm}$ extension; $10 \mathrm{~cm}$ vertical displacement, down to southeast.

23-30. Cracks trending N75W; $220 \mathrm{~mm}$ extension and $430 \mathrm{~mm}$ vertical displacement.

23-31. $2 \mathrm{~m}$-wide zone containing discontinuous cracks as much as $35 \mathrm{~cm}$ wide, $65 \mathrm{~cm}$ deep, and $10 \mathrm{~cm}$ vertical separation down to north. 2 to 3 cracks form zone. Zone widens to $4 \mathrm{~m}$ toward west. Zone trends N75W.

23-32. Cracks cross jogging trail. Maximum width $15 \mathrm{~cm}$; maximum depth $30 \mathrm{~cm}$; vertical separation $10-15 \mathrm{~cm}$, down to north; slope north of school may be fault scarp, trend N40W. Cracks continuous westward to zone of cracks in parcel road; dies out near school yard fence. 
23-33. Crack crosses perimeter road of the farm; width about $15 \mathrm{~cm}$; vertical separation $15-20 \mathrm{~cm}$; trend $\mathrm{N} 65 \mathrm{~W}$. Crack traced to tree farm road on west side of school fence. Maximum width $50 \mathrm{~cm}$; maximum depth $1 \mathrm{~m}$; vertical separation $20 \mathrm{~cm}$; trend $\mathrm{N} 60 \mathrm{~W}$.

23-34. Crack at 23-33 less distinct toward east. Lost under paving in handball-court; cracks in macadam along projection. Cracks across handball and volley ball courts show 2-3 cm right-lateral separation where they cross painted lines.

23-35. Several small cracks cross road here. Trend N40W; width about $3 \mathrm{~cm}$; no apparent vertical separation. Cracks are on trend with crack at 23-33.

23-36. Crack crosses road and extends into Christmas tree area on both sides of road. Maximum width $50 \mathrm{~cm}$; maximum depth $120 \mathrm{~cm}$; vertical separation $20 \mathrm{~cm}$, down to northwest; trend N35E.

23-37. Large en echelon cracks trending N30-60W; horizontal displacement 70-240 mm; no apparent vertical offsets.

23-38. Crack set trends N45-55W; horizontal displacement $20 \mathrm{~mm}$; vertical displacement < $10 \mathrm{~mm}$.

23-39. N40W-trending cracks; $10-30 \mathrm{~mm}$ horizontal offset.

23-40. Landslide headscarp or large slump in road, 50-80 feet long; crack swings from N30W to N60W; horizontal offset $220 \mathrm{~mm}$; vertical displacement $240 \mathrm{~mm}$, down to south.

23-41. Cracks trending N55W; $130 \mathrm{~mm}$ horizontal offset; $40 \mathrm{~mm}$ vertical displacement, down to northeast.

23-42. Cracks in driveway trend N55-80W; $65-75 \mathrm{~mm}$ horizontal offsets; $40 \mathrm{~mm}$ vertical displacement with sense variable.

23-43. Cracks trending N55W to E-W; extension $100 \mathrm{~mm}$; about $10 \mathrm{~mm}$ vertical displacement, down to south.

23-44. Large crack in dirt (logging?) road trending N40W; extension up to $1800 \mathrm{~mm}$; vertical displacement $60 \mathrm{~mm}$, down to southwest.

24-1. $4 \mathrm{~cm}$ vertical displacement, down to southwest.

24-2. Crack with right lateral displacement; $20-40 \mathrm{~cm}$ wide; $40 \mathrm{~cm}$ extension, $10 \mathrm{~cm}$ vertical displacement, down to southeast.

24-3. Crack with $15 \mathrm{~cm}$ right lateral displacement.

224-4. 2-7 cm extension; $2-7 \mathrm{~cm}$ vertical displacement, down to southeast.

24-5. $6 \mathrm{~cm}$ extension; $8 \mathrm{~cm}$ vertical displacement, down to southeast.

24-6. Crack with $10 \mathrm{~cm}$ left lateral displacement; $18 \mathrm{~cm}$ vertical displacement, down to southeast; $25 \mathrm{~cm}$ extension; $30 \mathrm{~cm}$ net displacement.

24-7. 1-2 cm extension. 
24-8. Crack with $15 \mathrm{~cm}$ right lateral displacement; $16 \mathrm{~cm}$ vertical displacement, down to southeast; less than $26 \mathrm{~cm}$ extension; net displacement less than $30 \mathrm{~cm}$.

24-9. Crack varying from N35-50W through its midsection; $40 \mathrm{~cm}$ left lateral displacement; $30-60 \mathrm{~cm}$ wide; $30 \mathrm{~cm}$ vertical displacement.

24-10. Well plugged at 53' depth.

24-11. Crack with $5 \mathrm{~cm}$ right lateral displacement, $11 \mathrm{~cm}$ vertical displacement, down to southeast; $1 \mathrm{~cm}$ extension.

24-12. Crack with $13 \mathrm{~cm}$ vertical displacement, down to south; $8 \mathrm{~cm}$ extension.

24-13. Crack with $85 \mathrm{~cm}$ right lateral displacement; $50 \mathrm{~cm}$ vertical displacement, down to southeast; $40 \mathrm{~cm}$ extension; $95 \mathrm{~cm}$ net displacement.

24-14. $25 \mathrm{~cm}$ extension.

24-15. Crack with $5 \mathrm{~cm}$ left lateral displacement; $3 \mathrm{~cm}$ vertical displacement; $12 \mathrm{~cm}$ extension; $13 \mathrm{~cm}$ net displacement.

24-16. Crack with $23 \mathrm{~cm}$ left lateral displacement; $20 \mathrm{~cm}$ extension; $30 \mathrm{~cm}$ net displacement.

24-17. Crack with $15 \mathrm{~cm}$ right lateral displacement; $25 \mathrm{~cm}$ vertical displacement, down to southeast; $43 \mathrm{~cm}$ extension; $46 \mathrm{~cm}$ net displacement.

24-18. $3 \mathrm{~cm}$ vertical displacement, down to north.

25-1. $10 \mathrm{~cm}$ extension.

25-2. $13 \mathrm{~cm}$ displacement at azimuth $120^{\circ}$; vertical displacement $15 \mathrm{~cm}$, down to southwest.

25-3. $30 \mathrm{~cm}$ extension; $30 \mathrm{~cm}$ vertical displacement, down to southwest.

25-4. $30 \mathrm{~cm}$ vertical displacement, down to southeast; up to $45 \mathrm{~cm}$ extension.

25-5. $8 \mathrm{~cm}$ extension at azimuth of $210^{\circ}$.

25-6. $10 \mathrm{~cm}$ extension at azimuth $245^{\circ}$.

25-7. Crack through driveway and retaining wall with $15 \mathrm{~cm}$ extension; $32 \mathrm{~cm}$ vertical displacement, down to northeast.

25-8. 50 to $60 \mathrm{~cm}$ vertical displacement, down to southeast.

26-1. Sinistral en echelon crack trending N5W; displacement $22 \mathrm{~cm}$ to N20E with average plunge of $15^{\circ}$.

26-2. Sinistral fracture; trend N25W; displacement $5 \mathrm{~cm}$ to N25E with plunge of $<5^{\circ}$.

26-3. Sinistral fracture with trend of N15W; displacement $7-20 \mathrm{~cm}$ to N43E with plunge of $10^{\circ}-20^{\circ}$. 
26-5. Sinistral fracture trending N2W; displacement $50 \mathrm{~cm}$ to N25E with plunge of $20^{\circ} ; 2$ to $3 \mathrm{~m}$ deep.

26-6. Sinistral crack trending N25W; $6 \mathrm{~cm}$ displacement to $\mathrm{N} 26 \mathrm{E}$, plunge $<5^{\circ}$.

26-7. Sinistral, right stepping crack trending N25W; displacement $11 \mathrm{~cm}$ to N35E with plunge of $15^{\circ}$.

26-8A. Set of dilatational, sinistral cracks trending N22W with displacement $2.5 \mathrm{~cm}$ to N40E, plunge $0^{\circ}$.

26-8B. Trend N20W; displacement $2 \mathrm{~cm}$ to N35E, plunge $0^{\circ}$.

26-8C. Dextral crack trending N47W; displacement $4 \mathrm{~cm}$ to N80W; fracture set including $\mathrm{A}, \mathrm{B}$, and $\mathrm{C}$ extends for over $75 \mathrm{~m}$ through orchard.

26-9. Dextral crack trending N62W; displacement $30 \mathrm{~cm}$ to W, plunge $25^{\circ}$.

26-10. Dextral crack trending N70W; displacement $3 \mathrm{~cm}$ to N70E.

26-11. En echelon crack set about $10 \mathrm{~m}$ wide. Crack trending N45W; sinistral; $2.8 \mathrm{~cm}$ displacement to $\mathrm{N}$, plunge $0^{\circ}$.

26-12. Crack trending N72W; $7 \mathrm{~cm}$ displacement to N64W, plunge $0^{\circ}$.

26-13. En echelon, dilatational, sinistral cracks trending N44W; displacement $1 \mathrm{~cm}$ to N44E, plunge $0^{\circ}$.

26-14A. Sinistral crack; trend N5W; displacement $4 \mathrm{~cm}$ to N35E, plunge $<5^{\circ}$.

26-14B. Sinistral crack; trend N3W; displacement $8.5 \mathrm{~cm}$ to N39E, plunge $15^{\circ}$.

26-14C. Sinistral crack; trend N12W; displacement $3.5 \mathrm{~cm}$ to N60E, plunge $5^{\circ}$.

26-14D. Sinistral crack; trend N12W; displacement $5.5 \mathrm{~cm}$ to N70E, plunge $0^{\circ}$.

26-14E. Sinistral crack; trend N-S; displacement $2 \mathrm{~cm}$ to NS, plunge $0^{\circ}$.

26-14F. Sinistral crack; trend N5E; displacement $2 \mathrm{~cm}$ to N70E, plunge $0^{\circ}$.

26-15. Dextral crack trending N50W; $9 \mathrm{~cm}$ displacement to N70E, plunge $0^{\circ}$.

26-16. Ground failure crack curves from N40E to E-W. Where measured, crack trend is E-W; displacement $24 \mathrm{~cm}$ to $\mathrm{N}$, plunge $30^{\circ}$.

26-17. Crack trending N45W; $7 \mathrm{~cm}$ displacement to $\mathrm{S}$, plunge $35^{\circ}$.

26-18. Crack trending E-W; $2 \mathrm{~cm}$ displacement to $\mathrm{N} 50 \mathrm{E}$, plunge $0^{\circ}$.

26-19. Crack trending N45W; $7 \mathrm{~cm}$ displacement to N30E, plunge $50^{\circ}$.

26-20. Crack trending N40W; $16.4 \mathrm{~cm}$ displacement to $\mathrm{S} 12 \mathrm{~W}$, plunge $25^{\circ}$.

26-21. Crack trending N55W; $7.5 \mathrm{~cm}$ displacement to $\mathrm{S} 60 \mathrm{w}$, plunge $20^{\circ}$.

26-22. Crack trending N49W; $2 \mathrm{~cm}$ displacement to $\mathrm{S} 15 \mathrm{E}$, plunge $10^{\circ}$. 
26-23. Crack trending $\mathrm{N} 48 \mathrm{~W} ; 5 \mathrm{~cm}$ displacement to $\mathrm{S} 32 \mathrm{~W}$, plunge $52^{\circ}$.

26-24. Crack trending N70W; $2 \mathrm{~cm}$ displacement to $S 10 \mathrm{~W}$, plunge $0^{\circ}$.

26-25A. Trend N45W; displacement $10 \mathrm{~cm}$ to $\mathrm{N} 45 \mathrm{E}$, plunge $10^{\circ}$.

26-25B. Trend N40W; displacement $1.5 \mathrm{~cm}$ to N45E, plunge $0^{\circ}$.

26-26. Crack trending N75W; $5.5 \mathrm{~cm}$ displacement to $\mathrm{S} 10 \mathrm{~W}$, plunge $20^{\circ}$.

26-27. Large slump scarp. Crack trending N70E; $22 \mathrm{~cm}$ displacement to S79E, plunge $62^{\circ}$.

26-28. Slump scarp; crack trending N62W; $4.4 \mathrm{~cm}$ displacement to $S$, plunge $15^{\circ}$.

26-29. Crack trending N67W; $4.6 \mathrm{~cm}$ displacement to S5E, plunge $10^{\circ}$.

26-30. Large crack system; trend N40W; displacement $26 \mathrm{~cm}$ to N5W, plunge $55^{\circ}$.

26-31. Same crack system as $26-30$; trend N53W; displacement $24 \mathrm{~cm}$ to N10W, plunge $60^{\circ}$.

26-32. Same crack system as 26-30 and 26-31. Crack trends N37W; displacement $3.3 \mathrm{~cm}$ to $\mathrm{N} 30 \mathrm{E}$, plunge $0^{\circ}$.

26-33. Crack trending N70W; $10 \mathrm{~cm}$ displacement to N30W, plunge $45^{\circ}$. En echelon cracks in this set over $3 \mathrm{~m}$ deep.

26-34. Crack trending N75E; $22 \mathrm{~cm}$ displacement to N60W, plunge $40^{\circ}$.

26-35. Large anastomosing crack system that crosses Old San Jose Road. Crack trend $\mathrm{N} 65 \mathrm{~W}$; displacement $20.5 \mathrm{~cm}$ to $\mathrm{N} 25 \mathrm{E}$, plunge $30^{\circ}$.

26-36. Same system as 26-35; crack trend N85W; displacement $10.2 \mathrm{~cm}$ to S15E, plunge $25^{\circ}$. 